\title{
UM PERCURSO SOBRE O FALO NA PSICANÁLISE: PRIMAZIA, QUERELA, SIGNIFICANTE E OBJETO $a^{*}$
}

Ana Costa e Flavia Bonfim

\author{
Ana Costa \\ Psicanalista, \\ professora da UERJ \\ e coordenadora da \\ Rede de Pesquisa \\ Escritas da \\ Experiência. Autora \\ dos livros: Clinicando \\ (Appoa, 2008); \\ Sonhos (Jorge Zahar, \\ 2006); Tatuagem \\ e marcas corporais e \\ Atualizações do sagrado \\ (Casa do Psicólogo, \\ 2003). \\ Flavia Bonfim \\ Psicanalista, \\ psicóloga \\ graduada e com \\ especialização \\ em Psicanálise e \\ Laço Social pela \\ UFF, mestre em \\ Pesquisa e Clínica \\ em Psicanálise pela \\ UERJ e supervisora \\ de estágio do Setor \\ de Psicologia Geral \\ da Associação \\ Fluminense de \\ Reabilitação.
}

RESUMO: As considerações sobre o falo na história psicanalítica não são unânimes e lineares. Freud o situou como elemento fundamental da estruturação sexual; todavia, semelhante valor não lhe foi atribuído pelos pós-freudianos, dando início ao que Lacan denominou de "querela do falo". Lacan, apesar de ter situado o falo como significante, promoveu deslocamentos e nuances na forma de abordá-lo - articulou-o ao objeto a, seguido da identificação ao semblante e culminando na lógica do todo e não-todo fálico. Estas formulações mostram relação com as construções a respeito do real; portanto, não revogam as contribuições anteriores, mas redimensionam o aparato teórico-clínico de Lacan.

Palavras-chave: Falo, sexualidade, significante, objeto a, não-todo fálico.

ABSTRACT: A course in psychoanalysis about the phallus: primacy, quarrel, significant and object a. The considerations about the phallus in psychoanalytic history are not unanimous and liners. For Freud, the phallus is a fundamental element of sexual organization, however, the same value wasn't assigned by the post-Freudian, initiating to what Lacan called the "quarrel of the phallus". Lacan, despite having set the phallus as signifier, promoted changes and nuances in the way of approaching it — articulated to a object, followed by the identification to semblant and culminating in logic the phallus all and not-whole. These formulations reveal relationship with the theorizing on the real, therefore, not revoke the earlier contributions, but resize the theoretical apparatus and clinical of Lacan.

Keywords: Phallus, sexuality, significant, object a, non-all phallic.

\footnotetext{
* Artigo redigido a partir da dissertação de mestrado apresentada ao Programa de Pós-Graduação em Pesquisa e Clínica em Psicanálise da Universidade do Estado do Rio de Janeiro (Uerj).
} 
$\Lambda_{\text {cos, as construções a seu respeito ao longo da história da psicanálise não são }}$ unânimes e lineares. Sendo um conceito fundamental presente na obra freudiana no que se refere à hipótese da primazia fálica na estruturação sexual de ambos os sexos, não podemos afirmar que semelhante valor lhe foi atribuído pelos pós-freudianos. Estes, ao teorizarem sobre a sexualidade feminina, promoveram um desvio quanto ao lugar do falo na teoria freudiana sobre a sexualidade. Com Lacan, vemos tal embate ser solucionado, visto que o falo passa a ser esclarecido em sua função, ou seja, o falo é um significante, e todo desejo, seja do homem ou da mulher, possui referência fálica. Entretanto, o mesmo Lacan, mais à frente em seu ensino, apresenta-nos outra dimensão do falo. Este é articulado a uma das formas do objeto a. O objeto a, por sua vez, apresenta estrutura irredutível ao significante.

Diante disso, este ensaio versa sobre o conceito de falo, tendo como objetivo geral traçar um percurso do mesmo na história da psicanálise. E, de modo especial, procuramos aqui extrair consequências da articulação entre falo e objeto a proposta por Lacan, com o objetivo de apontar em que perspectiva se insere esta elaboração teórica.

\section{A PRIMAZIA FÁLICA EM FREUD}

Ao abordar a noção de falo, é interessante pensar sobre a origem desse termo na psicanálise. Lacan, ao fazer referência ao falo, pondera que "não foi sem razão que Freud extraiu-lhe a referência de simulacro que ele era para os antigos." (1998a [1958], p.359). Em seguida, Lacan (1999 [1957-58]) afirma que o falo, na antiguidade grega, não era idêntico ao órgão, seja em termos de acessório do corpo, prolongamento ou em seu estado de funcionamento - sendo seu uso mais predominante no sentido de simulacro, uma insígnia. Segundo este autor, isto nos coloca na pista do falo em seu papel preponderante como representante do desejo.

A representação fálica era bastante familiar no cotidiano do mundo romano, egípcio, grego e etrusco antigo. Imagens de falo podiam ser encontradas em muros, joias, sinos, lamparinas, máscaras, paredes e tigelas, simbolizando a fertilidade e a força apotropaica (sua bondade trazia boa sorte e sua agressividade afastava o azar e o mau-olhado, cf. Cavicchioli, 2008). Isto é, os antigos viam no falo um objeto poderoso, perpetuador da vida de todas as espécies do planeta e neutralizador das coisas ruins. Também era possível encontrar na antiguidade o culto ao falo, manifesto em procissões religiosas (falofórias) em que se levavam uma ou várias imagens fálicas. Esse tipo de culto era um antídoto contra a impotência; traduzia-se em símbolo de fecundidade (BRANDÃO, 1991). Frente 
a este lugar atribuido à referência fálica na antiguidade, podemos associar a supervalorização do falo e sua ligação com a sexualidade. Caso não haja a veneração ao objeto fálico, a virilidade fica ameaçada. Sua articulação com o desejo, com a sexualidade, está aí demarcada e Freud não desprezou o valor que ele tinha no mundo antigo, muito possivelmente porque em sua clínica tenha encontrado eco de sua importância.

Por sua vez, Freud utiliza mais o termo "pênis" do que "falo", servindo-se com frequência maior de sua forma adjetiva (fálico/a), ao mesmo tempo que sustenta que "o que está presente, portanto, não é uma primazia dos órgãos genitais, mas uma primazia do falo" (1923b, p.158, grifo do autor). Os advertidos sabem que, em psicanálise, não podemos confundir falo com pênis; contudo, negar a articulação entre esses termos é uma imprecisão. Serge André comenta que, com o termo falo, Freud “introduz uma nuance: se o falo tem relação íntima com o órgão masculino, é na medida em que designa o pênis enquanto faltoso ou suscetível de vir faltar." (1998, p.172). É a falta sempre presente, seja como ameaça ou como fato consumado. De modo mais apurado, o que é sustentado como elemento organizador da sexualidade não é o órgão genital masculino, mas a representação psíquica imaginária e simbólica construída a partir desta região corporal do homem.

Para abordar esta intrínseca relação entre falo e sexualidade, Freud articula-o ao mito do Édipo e ao complexo de castração. Com os mitos, a perspectiva freudiana procura pensar "os começos”, “a origem”, sendo fundamentalmente por meio do complexo edípico que ele responde à indagação "quem sou eu?”, que se desdobra em "sou homem ou sou mulher?". Assim, trata-se de uma referência mitológica que busca dar conta do impossível, do real em jogo no campo sexual. Em torno do complexo edipiano fez girar a questão da diferença anatômica enquanto significante, no qual podemos situar o falo como representante.

Tais construções teóricas foram desenvolvidas com mais consistência por Freud entre as décadas de 1920 e 1930, sobretudo após suas reavaliações sobre a sexualidade feminina. Apesar disso, não convém ignorarmos o fato de que alguns pormenores dessas discussões já estavam presentes na obra freudiana desde 1905, especificamente nos Três ensaios sobre a teoria da sexualidade. Ali, Freud nos fala do seio materno como o primeiro objeto de investimento da criança e cita a noção de complexo de castração e de inveja do pênis. Já então sustenta que o clitóris é a zona erógena dominante nas meninas. Essas considerações foram retomadas, articuladas e depuradas no referido momento posterior do pensamento freudiano, mas encontram expressão igualmente nos Três ensaios.

É também neste livro que podemos localizar o que Freud (1905) denominou de "estágio fálico da organização" sexual infantil. Nos Três ensaios, propõe "as fases do desenvolvimento da organização sexual” (oral e anal), incluindo, por 
meio de acréscimos posteriores de parágrafos e notas de rodapé, uma terceira fase - a fálica. Nesta, a criança de ambos os sexos conhece apenas um tipo de órgão sexual, o masculino. Isso nos leva à consideração de que não há registro no inconsciente do Outro sexo. Freud (1923) escreve que, nesta fase, existe a masculinidade, mas não a feminilidade; a antítese ocorre entre fálico e castrado. Assim, segundo ele (1924), na fase fálica, o desenvolvimento sexual infantil avança até um determinado ponto no qual o órgão genital masculino assume papel principal, estando a vagina irrevelada. Comenta André: “O que não quer dizer, certamente, que a existência material da vagina seja ignorada, mas ela não é conhecida como outra coisa que não um falo furado.” (1998, p.191, grifo do autor).

Freud (1938) escreve-nos que ao longo da fase fálica a sexualidade infantil atinge seu apogeu e aproxima-se da dissolução; porém, depois desse período, meninos e meninas seguem caminhos distintos, sinalizando a dissimetria entre os sexos quanto aos complexos de Édipo e de castração — ponto demarcado por Freud desde 1924. Recalde comenta: “A menina entra no Édipo pelo mesmo motivo que o menino sai: o complexo de castração. Freud não renunciará nunca a esta assimetria inquestionável.” (2008, p.105-106, tradução livre).

$\mathrm{Na}$ fase fálica, o menino ingressa no complexo edipiano e, com ele, a masturbação associa-se às fantasias incestuosas em relação à mãe. Contudo, as ameaças de castração acrescidas à visualização da ausência de pênis nas mulheres (confronto com a castração do Outro) ganham significação e o menino passa a temer a perda de seu órgão (FREUD, 1924). A menina, na fase fálica, também é forçada a se confrontar com a diferença anatômica entre os sexos, mas o que ocorre no caso dela? Essa pergunta está respondida por Freud desde os Três ensaios: "Está pronta a reconhecê-lo de imediato e é tomada pela inveja do pênis, que culmina no desejo de ser também um menino, tão importante em suas consequências.” (1905, p.183).

Mais tarde, nos artigos "Algumas consequências psíquicas da distinção anatômica entre os sexos" (1925), "Sexualidade feminina" (1931) e "Conferência XXXIII — Feminilidade” (1932), Freud explicita esta discussão de maneira mais detalhada e nos escreve que a menina, ao se confrontar com a castração, renuncia à mãe como objeto de amor, culpa-a por tê-la feito castrada e, em função disto, dirige-se amorosamente para o pai. No entanto, a situação feminina só se concretiza se o desejo de possuir um pênis for substituído pelo desejo de ter um bebê. Assim, a busca pelo pai, marcando sua entrada no Édipo, acontece tanto porque ele é o suposto portador do falo, como também porque é capaz de lhe dar um filho como substituto simbólico fálico.

Sobre essa aproximação entre acesso à feminilidade e desejo de ter um bebê (correlato do desejo de possuir um falo), Recalde (2008) aponta que a 
maternidade será a proposta freudiana para solucionar a questão da inveja do pênis, assim como a via amorosa (busca do parceiro) e a falicização do corpo. Por outro lado, a autora argumenta que o desejo do falo não se resolve quando a mulher torna-se mãe, ou ao eleger um parceiro (suposto de tê-lo), pois o falo não é o órgão masculino. Estas são apenas maneiras imaginárias com objetivos inoperantes de suturar uma falta irredutível.

Sendo assim, será em torno do falo — enquanto possibilidade de perdê-lo ou na vontade de tê-lo — que Freud organizará a questão da sexualidade humana, procurando, por meio dos complexos de Édipo e de castração, explicar como o sujeito acede ao posicionamento subjetivo feminino ou masculino. Deste modo, Zack (2008) chama a atenção para o Édipo freudiano em sua dimensão estruturante, pois ele se apresenta como a base determinante do destino do sujeito, sem deixar de levar em conta a responsabilidade e o consentimento do mesmo, que implica seu posicionamento de gozo diante da confrontação com o desejo do Outro e com a castração.

\section{OS PÓS-FREUDIANOS E A "QUERELA DO FALO"}

A teoria freudiana, ao conferir ao falo o lugar central de elemento estruturador da sexualidade, recebeu a crítica de ser falocêntrica e de propor uma hierarquização entre os sexos. Espelhados pelo movimento feminista que ganhava força na época, surgia também na psicanálise, entre as décadas de 1920 e 1930, o questionamento sobre a primazia do falo e a falta fálica como sendo o núcleo do ser feminino, iniciando-se fervorosas discussões sobre a feminilidade, mas, sobretudo, sobre a função do falo nas teorizações psicanalíticas - discussões que Lacan denominou de "querela do falo". Retomando estes debates, que fazem parte do percurso sobre o conceito de falo na psicanálise, seguimos apresentando as construções dos pós-freudianos por meio de quatro eixos: 1) O falo como objeto interno da mãe e o complexo de Édipo na teoria kleiniana; 2) Ernest Jones e a natureza defensiva da fase fálica nas mulheres; 3) Hélène Deutsch e o masoquismo feminino; 4) A teoria cultural de Karen Horney.

Na teoria kleiniana, foi possível verificar um distanciamento quanto à doutrina de Freud no que se refere ao Édipo e ao lugar do falo na experiência do sujeito. Em sua elaboração teórica, Klein ordena o que se passa com a criança e sua mãe por meio das noções de posição esquizoparanoide e posição depressiva, sinalizando que o complexo de Édipo começa a se desenvolver a partir desta última fase.

Klein (1986 [1952]) afirma que, no complexo de Édipo primitivo, a criança imagina que o pênis, ou o pai, faz parte da mãe (fantasia dos pais combinados), idealizando que ela contém tudo o que é desejável: seio, bebês, fezes e pênis. Sendo assim, o Édipo precoce é caracterizado por uma ambivalência acirrada, pela 
predominância de tendências orais e pela indefinição quanto ao objeto sexual. O desejo de união genital é uma modificação da tentativa de recuperar a relação primitiva com o seio que foi danificado, isto é: o desejo de restaurar o corpo da mãe se processaria por meio da relação genital, que restituiria à imagem da genitora os seus objetos (SEGAL, 1973). Criticando tal formulação, Rabinovich (2009) pondera que ao final do Édipo o que temos na teoria de Klein é o luto da posição depressiva, e não um luto frente à renúncia aos objetos edípicos tal como encontramos em Freud.

Não obstante, o lugar da figura materna nesta teoria foi hipervalorizado; logo, o papel do pai enquanto lei ordenadora foi desprezado e, consequentemente, a função fálica na economia subjetiva também. De modo mais específico, o pai desempenha seu lugar na trama infantil como um objeto alternativo frente ao medo e à possibilidade fantasística de perder a mãe. Quanto ao falo, ele foi equiparado e tomado como um dos objetos internos da mãe, tal como o seio, o leite, os bebês e as fezes, negligenciando seu valor estruturador do campo sexual. De forma mais radical sobre a função fálica, Rabinovich comenta:

“A significação fálica aparece aqui como substituto progressivo da significação do seio. Ali é onde o Édipo só desempenha seu papel na medida em que o pênis paterno se apresenta como um substituto da medida-padrão dos objetos que é o seio materno." (2009, p.61)

Bebendo na fonte kleiniana, temos Ernest Jones. Em sua teoria, Jones (1977 [1927]) leva em consideração a noção de erotismo oral e sadismo, postulando que, no desenvolvimento da menina, o estágio sádico se colocaria mais tarde, de modo que nem o estágio oral ou o clitoriano receberiam catexias sádicas poderosas. Segundo Pollo (2003), para Jones, o estágio feminino assemelha-se ao estágio alimentar e o sadismo é provocado pela frustração oral. Não havendo essa frustração, o clitóris não se associaria a uma atitude masculina ativa. Sem o estágio sádico, ocorreria, então, a passagem bem-sucedida do estágio oral ao estágio anal, sendo a boca e o ânus equivalentes do órgão sexual feminino.

Dito de outra forma: Jones defende o desenvolvimento feminino por meio do processo boca-ânus-vagina, no qual estaria posto uma identificação com a mãe. Logo, a fase fálica na menina foi compreendida como uma forma moderada de identificação ao pênis paterno (diferente da intensidade dessa identificação no caso das mulheres homossexuais), tendo uma natureza secundária e defensiva, não correspondendo a uma etapa verdadeira do desenvolvimento da mulher heterossexual (JONES, 1977 [1927]). Identificamos, nas construções de Jones, que a feminilidade não é mais especificada através da função fálica, mas pelo deslocamento da libido — o que assegura o conhecimento da vagina. 
Diante disso, Lacan (1995 [1956-57]) nos diz que não é porque possa haver algum tipo de experiência precoce na menina que provoque sensações na região vaginal que a hipótese de Freud pode vir a ser contestada. "A afirmação de Freud está fundada em sua experiência.” (idem, p.98). Intensificando sua crítica, Lacan assinala: "se a questão fosse apenas uma migração da pulsão erótica, veríamos traçada a via real da evolução da feminilidade no nível biológico." (1999 [1957-58], p.287). O que Jones parece não notar, conforme indica Lacan (idem, ibidem), é que o Édipo não só fabrica a mulher, mas o homem também. Para os dois sexos, o que temos é um artifício significante.

Discutindo também sobre a feminilidade, há a psicanalista Deutsch e suas construções sobre o papel do masoquismo na vida mental das mulheres. Deutsch (1979 [1925]) aceita e reconhece uma fase fálica no desenvolvimento da menina - afinando-se um pouco com a teoria freudiana nesse ponto. Todavia, esta autora considera que o desenvolvimento de uma fase genital na mulher se processa por um deslocamento da libido oral (equivalência entre boca e vagina) associado à estimulação do pênis do parceiro no ato sexual. A mulher, ao descobrir este novo orgasmo em seu próprio corpo, reconhece-se, então, sujeita de forma masoquista ao pênis — que a guiará a sua nova fonte de prazer. Isso porque a vagina não desempenha nenhum papel erógeno até que se proceda a primeira relação sexual. Confere-se, assim, que a incidência simbólica do falo nesse contexto encontra-se excluída - o que é apresentado é seu caráter puramente biológico, imaginário, com a experiência do ato sexual.

Assim, para Deutsch, a vagina assumiria uma funcionalidade na mulher semelhante ao pênis no homem. Ao defender uma identificação funcional entre pênis e vagina, que permitiria à mulher superar o trauma da castração, ela trabalhou - tal como verifica Pollo (2003) — recusando a equivalência simbólica mediatizada pelo falo (pênis $=$ bebê $=$ fezes $=$ dinheiro) postulada por Freud.

Além disso, a psicanalista aproxima feminilidade e reprodução articuladas à questão do masoquismo. Para ela, o sexo representa a intenção e o começo do parto, bem como este é o fim do ato sexual. O "parto é para a mulher uma orgia de prazer masoquista." (DEUTSCH, 1979 [1925], p.51, tradução livre). Afirma ainda que o desejo de ter um pênis é substituído pelo desejo de ser violada pelo pai e, com isso, receber um filho seu, concedendo à vida mental das mulheres a tríade masoquista: castração = violação = parto. Diante disso, Soler (2005) afirma que a ideia da "mulher masoquista" não é uma tese freudiana. Freud introduziu essa discussão e a explorou; porém, sinalizou que há mulheres e homens masoquistas, sabendo reconhecer que esta não era uma via de resposta à questão do feminino.

Encerrando a "querela do falo" posta pelos pós-freudianos, Karen Horney enfatiza demasiadamente aspectos sociais e culturais presentes na história de vida 
do sujeito, negligenciando o que de fato interessa ao campo psicanalítico - a dimensão inconsciente. Para Horney (1966 [1939]), o complexo de Édipo e de castração, bem como a inveja do pênis, não são eventos típicos e decisivos para o desenvolvimento da sexualidade da mulher. Segundo a autora (1991 [1924]), a inveja do pênis decorreria do sentimento de desvantagem nas possibilidades de gratificação que os meninos adquirem em comparação com as meninas. O menino pode ver e segurar seu órgão genital — sendo isto interpretado inconscientemente como autorização para se masturbar. Assim, a menina se sentiria lesada por não dispor de mesma permissão em função de sua disposição anatômica, tendo a impressão de estar sujeita a restrições na satisfação de componentes pulsionais.

Isso, contudo, não é decisivo para que a inveja de pênis se instale na mulher, pois, quando a falta de pênis se coloca como desvantagem para a menina, ela tem como saída a identificação com a mãe. É somente quando sofre rejeição do pai, associada a uma identificação com ele, que a menina é levada de volta à fase pré-genital da inveja do pênis, conferindo o estabelecimento de relações com homens baseadas em vingança e decepção (HORNEY, 1991 [1924]). A autora também aponta que fatores culturais e sociais ajudam a esclarecer os desejos de masculinidade. O primeiro deles seria que o desejo de ser um homem tem relação com o desejo de possuir qualidades ou privilégios (força, coragem, independência, liberdade sexual e sucesso) mais comuns aos homens na cultura vigente (HORNEY, 1966 [1939]).

Sejam quais forem os argumentos tomados por Horney, todos desembocam — assim como vimos na perspectiva dos outros pós-freudianos — numa posição distinta da qual Freud situou a problemática da feminilidade e da primazia fálica. Talvez o ponto de maior equívoco tenha sido a maneira como o falo foi apreendido no discurso freudiano, fazendo com que a referência fálica fosse entendida absolutamente como equivalente ao pênis. Assim, o falo, nestas construções, foi apresentado em sua dimensão de realidade ou imaginária, porém, seu estatuto simbólico ficou desprezado, tornando-se necessário o esforço lacaniano de situá-lo como significante do desejo, ordenador do campo sexual em ambos os sexos.

\section{O FALO COMO SIGNIFICANTE EM LACAN}

De acordo com Rabinovich (2009), é possível identificar no primeiro ensino de Lacan um crescente destaque adquirido pelo falo em suas teorizações, desde o último capítulo do Seminário 3 (As psicoses), intitulado "O falo e o meteoro", passando pelo Seminário 4 (A relação de objeto) e chegando ao Seminário 5 - (As formações do inconsciente). No Seminário 3, Lacan constata a foraclusão do Nome-do-Pai nas psicoses, indicando que a significação fálica também está ausente nesta 
estrutura. Assim, segundo Rabinovich (op. cit.), Lacan inicia uma investigação sobre o papel do falo na neurose e na perversão. É em função disso que, nos seminários seguintes, encontramos o desenvolvimento da temática da falta de objeto (Livro 4), desembocando na discussão sobre a sexualidade, desejo, Édipo e castração (Livro 5). Vejamos cada um deles.

A discussão em torno das três formas da falta de objeto apresentada no Seminário 4 permite inferir que a construção subjetiva não se realiza por meio da relação do sujeito com seus objetos, mas com a falta deles, sendo o falo - enquanto ausente $(-\varphi)$ - um objeto primordial dentre tantos outros. Neste livro, o falo, como objeto primordial do desejo, começa sendo localizado no imaginário e termina posicionado no simbólico. O falo (- $\varphi$ / imaginário) operando na castração só existe como falta, enquanto imagem negativa, e isso é eminentemente simbólico, ao passo que consideramos que o símbolo implica a barra sobre algo que existe.

No Seminário 5, encontramos duas aulas que retomam o Édipo freudiano a partir de uma formulação em três tempos não cronológicos, mas lógicos, nas quais assistimos a hipótese edípica ser amarrada à inscrição do registro simbólico. No primeiro momento, temos o falo como objeto com a qual a criança se identifica, visto que deseja o desejo da mãe. A criança está na posição de ser o falo - objeto do desejo do Outro. Já no segundo tempo, a criança é desalojada do lugar de ser o falo para ter ou não ter o falo, podendo vir a se constituir como um sujeito desejante, e isso guarda profunda ligação com a mensagem que o pai dirige à mãe. O falo passa de objeto imaginário do desejo da mãe a significante do desejo do Outro. Por último, a criança tem acesso à significação fálica, possibilitando, assim, situar-se na partilha dos sexos.

Ratificando tais construções teóricas, há um importante texto no escrito “A significação do falo” (1998 [1958]), em que podemos encontrar elementos fundamentais sobre a noção de falo como significante. Ali, Lacan retoma o embate entre Freud e os pós-freudianos, propondo-se a problematizar as discussões em torno da questão da primazia fálica na estruturação sexual tanto do homem quanto da mulher. Enfaticamente, ao longo do texto, Lacan (1998 [1958]) argumenta que a relação do sujeito com o falo se estabelece sem considerar a distinção anatômica entre os sexos e - tal como Freud - defende ser a partir da falta fálica que podemos abordar a problemática concernente à feminilidade. Diante disso, o esforço lacaniano foi além de apenas rebater as formulações dos pós-freudianos, mas procurou estabelecer o real lugar do falo nas teorizações de Freud — lugar que vinha sendo desconsiderado por esses autores. Sendo assim, ele afirma:

“O falo é aqui esclarecido em sua função. Na doutrina freudiana, o falo não é uma fantasia, caso se deva entender por isto um efeito imaginário. Tampouco é, como tal, um objeto (parcial, interno, bom, mau etc.), na medida em que esse termo 
tende a prezar a realidade interessada numa relação. E é menos ainda o órgão, pênis ou clitóris, que ele simboliza." (LACAN, 1998 [1958], p.696)

Em se tratando da noção de falo e fase fálica encontramos certa dificuldade, se a tomamos numa racionalidade biológica, considera Lacan (1999 [1957-58]). Os pós-freudianos parecem ter se orientado por este viés. Acrescenta Lacan que o problema desaparece quando o falo é elevado em seu papel de significante. Tomar o falo como significante não impede que ele tenha em sua origem a dimensão imaginária do pênis, mas até mesmo nesta origem é possível encontrar certa propriedade (aparecimento/desaparecimento; ereção/detumescência) para desempenhar sua função significante.

Lacan (1998 [1958]) demarca bem que o falo tem uma função constitutiva, pois introduz o sujeito em sua existência e em sua posição sexual. Isso só pode ser apreendido, diz ele, se o tomarmos como um significante indispensável pelo qual o desejo do sujeito é reconhecido como tal, quer seja homem ou mulher. Em suas palavras: "O falo é o significante privilegiado dessa marca, onde parte do logos se conjuga com o advento do desejo” (1998 [1958], p.692). Rabinovich (2005) esclarece-nos que o termo "logos" possui em grego três significações, a saber: linguagem, discurso e razão matemática/proporção. Sendo assim, encontramos nesta proposição a tentativa de reafirmar o falo como um significante privilegiado, que une sexualidade e linguagem, deixando uma marca sobre o corpo. A psicanalista é precisa ao dizer que "O falo suprirá o que o significante faz a sexualidade humana perder de natural, suprirá enquanto marca e, ao mesmo tempo, como cópula, como o que faz laço entre os sexos.” (2005, p.41).

\section{O FALO, O OBJETO A E OS AVANÇOS TEÓRICOS POSTERIORES}

No escrito “A significação do falo” e no Seminário 5, como acompanhamos, Lacan situa o falo como um significante fundamental operador na dimensão desejante do humano. Contudo, deparamo-nos, no Seminário 10 (A angústia, 2005 [196263]), com uma maneira bastante distinta de abordar a função fálica. Neste livro, Lacan introduz a noção de objeto pequeno a e confere-lhe cinco figurações: o seio, o ânus, o falo, a voz e o olhar. Estas fazem referência ao objeto a na medida em que se constituem como objetos perdidos. Mais precisamente, Lacan (ibid.) articula ao objeto a o caráter de objeto cedível, podendo ser encontrado em todas as formas que mantêm relação com ele.

Todos os objetos no percurso de Lacan, até esse seminário, podiam se tornar significantes. Agora, porém, ele nos apresenta um objeto com uma estrutura que não apenas se distingue do significante, mas é irredutível a ele. Para abordá-lo, ele o correlaciona ao fenômeno da angústia — sendo este o índice da presença 
subjetiva do objeto a, o modo como ele aparece na clínica da neurose. Por conseguinte, as cinco dimensões do a estarão também articuladas a este fenômeno.

Ao fazer referência ao falo e à questão da angústia, Vieira (2008) comenta que era comum designar no campo psicanalítico a mulher como castrada tendo que lidar com a falta de pênis, estando o homem livre de tal situação. No Seminário 10 , este arranjo se inverte, tendo o homem que se confrontar mais radicalmente com a angústia de castração. Trata-se, neste livro, de enfatizar a falta e não a completude, na medida em que não designa a ameaça de castração como incidindo sobre um ser total, ideal, mas procura assinalar a falta que aponta para a impossibilidade de um gozo absoluto.

Lacan (2005 [1962-63]) nos indica, então, que a detumescência na copulação — instrumento fora do combate, em seus termos - merece ser alvo de atenção, pois permite valorizar uma das dimensões da castração. E acrescenta, ainda: "O fato de o falo ser mais significativo na vivência humana por sua possibilidade de ser um objeto decaído do que por sua presença, é isso que aponta a possibilidade do lugar da castração na história do desejo” (idem, p.187). Referenciando-nos na categoria de objeto cedível, há algo que é arrancado no momento do orgasmo e, nesse momento, o sujeito ejacula — justamente no auge da angústia. Angustia-se, pois algo do gozo, do real e, portanto, sem explicação, toca o corpo. Assim, considera Lacan:

"O falo funciona em toda parte, numa função mediadora, exceto onde é esperado, ou seja, na fase fálica. É essa carência do falo, presente e irredutível em todos os lugares, não raro para a nossa grande surpresa, é o esvanecimento da função fálica no nível em que se espera que ele funcione, que constitui o princípio da angústia de castração." (2005 [1962-63], p.283)

Ou seja: é onde o falo deveria estar, no nível da completude (na mediação sexual), que ele falta. Vieira (2008) comenta que de tantos elementos corporais disponíveis, o pênis sustenta o jogo da falta exatamente porque costuma faltar. Demonstra-se como um suporte natural de uma ambiguidade em jogo: "tudo ou nada, poder absoluto ao longo de alguns minutos e representante flácido, DETUMESCENTE, da potência perdida no restante do tempo.” (VIEIRA, 2008, p.92).

Assim, de acordo com Leguil, no Livro 10, a questão fálica foi “remanejada numa abordagem da castração que não amarra exclusivamente às funções da lei [...] Ela passa a se ligar também ao real do gozo.” (2008, p.123). Há, desta maneira, "um novo status da angústia de castração, não mais referida à ameaça do Outro, a de um agente paterno, materno, mas ao fato biológico, anatômico, orgânico da detumescência da cópula.” (MILLER, 2005, p.34). Lacan ressitua a angústia de castração ao nível do órgão masculino, fazendo da detumescência 
— apagamento da função fálica no ato sexual — o princípio desta angústia, de modo que este princípio não mais se inscreve apenas no Édipo. Lacan reconhece a novidade que introduz com tal consideração, mas, por outro lado, considera que mesmo tendo situado o ponto da angústia no interior do sujeito, equivalendo orgasmo e angústia, nos diz que é "bastante evidente que não podemos desvincular disso $[(-\varphi)]$ o sinal da intervenção do Outro, uma vez que essa característica, desde o começo, sempre lhe foi imputada sob a forma das ameaças de castração.” (idem, p.285)

O impacto do que nos é articulado ao longo do livro sobre a angústia pode ter algo de enigmático e surpreendente, que não será possível apreender, nem acompanhar a fineza do que se inaugura se não avançarmos mais um pouco no ensino de Lacan. Vale destacar que o deslocamento da ênfase no falo como um significante no Seminário 10 será ajustado no ensino lacaniano, mas tal transformação diz da emergência de uma dimensão da experiência que até então Lacan pouco tinha trabalhado: o real na clínica. É também neste livro que começa a ser esboçada uma modificação quanto à questão da feminilidade.

No livro $A$ angústia, o objeto a comparece do lado do real; porém, isso será relativizado nos anos de 1970, quando assistiremos a uma semblantização do a. De modo mais preciso, podemos apontar que o objeto a e o falo foram elevados à categoria de semblante no decorrer do ensino lacaniano. Nesta perspectiva, no Seminário 18 (De um discurso que não fosse do semblante), Lacan sinaliza que a teoria analítica articula o que ele designa como objeto a, no que "ele vem preencher, como seio, excremento, olhar ou voz, o lugar definido como de mais-de-gozar" (2009 [1971], p.32). O ato de falar já implica a produção de mais-de-gozar. O mais-de-gozar é o efeito do discurso, e seu suporte é a metonímia. Diz do excedente da força pulsional não assimilável pelo trabalho de simbolização. Refere-se à dimensão do excesso, do desperdício de gozo da máquina da cadeia discursiva, que produz algo que venha na suplência da falta oriunda da castração. O mais-de-gozar situa-se como a mais-valia da economia psíquica. Ele expressa na repetição a maneira como cada sujeito ordena sua cadeia significante e assujeita-se à lei da castração.

A teoria psicanalítica enuncia justamente que essa relação de mais-de-gozar é essencial para o sujeito. Todavia, o mais-de-gozar, nos diz Lacan (idem), só se normaliza por uma relação com o gozo sexual, e esse gozo só se formula a partir do falo como seu significante. "O falo é, muito propriamente, o gozo sexual como coordenado com um semblante, como solidário a um semblante.” (idem, p.33). O falo é um significante - logo, um semblante. O semblante sempre envelopa o vazio, fazendo crer a existência de algo que não há. O semblante, ainda que se esforce por ocultar, o que oculta é nada. Dizendo de outro modo: “A função 
essencial do semblante - ao menos do semblante fálico — é pelo que não há, algo que dissimula e tapa o que não há." (BRODSKY, 2008 a, p.156).

Avançando na discussão sobre o falo, Lacan o localiza como uma função a regular o gozo de cada sexo. É, então, no Seminário 20 que o ensino lacaniano irá formalizar, com as fórmulas quânticas da sexuação, que a sexualidade provém da função fálica (função $\varphi x$ ); situar-se de um lado ou de outro, depende da maneira como o sujeito está assujeitado a ela: todo-fálico ou não-todo referido ao falo. Posicionar-se como homem implica estar totalmente submetido à lógica fálica. Situar-se numa posição feminina é estar também submetido ao falo, mas não por inteiro - o que tem como consequência o encontro do gozo fálico e gozo suplementar na mulher. Trata-se de um momento de avanço no que se refere à questão da feminilidade (LACAN, 1985 [1972-73]).

A noção de não-todo, portanto, faz referência ao modo particular da mulher experimentar que uma parte de si localiza-se submetida ao gozo fálico (gozo sexual, determinado pelo significante falo), enquanto a outra se situa no gozo Outro, no gozo do corpo (gozo que escapa ao domínio significante). Assim, a dimensão do significante, enquanto o que evoca algo além do que ele diz, e produz seu mais além, nos permite aproximar da ideia de não-todo e gozo suplementar. Portanto, é a partir do gozo fálico que podemos supor um outro gozo. O gozo fálico, por estar articulado ao significante, nos faz supor que há uma "outra coisa", um "mais-além". Posto isto, não se pode falar em um gozo Outro senão a partir do gozo sexual limitado do órgão (idem).

Morel assinala que a "linguagem impõe um significante único ao gozo: o falo” (1997, p.93). E do significante fálico, temos acesso ao gozo fálico, ao gozo do órgão. Caldas escreve que "O significante é precário para dizer da sexualidade. No entanto, paradoxalmente, a sexualidade só aparece e escoa pelo significante." (2008, p.382). O significante produz corpo de gozo, mas não-todo, de modo que um resto escapa ao império da linguagem. Ao mesmo tempo, podemos propor que o gozo sempre escapa a qualquer tipo de regulação, sendo o significante fálico incapaz de ordenar totalmente o sexual e o campo que ele abre. Assim, o gozo feminino leva em conta o limite, a regulação, mas, do mesmo modo, também o transpõe.

Diante disso, é possível concluir que Lacan não refutou completamente o Édipo freudiano; todavia, salientou que nele é possível identificar apenas a lógica fálica que permite estruturar a sexualidade masculina. Para tocar na questão da feminilidade, foi preciso que Lacan formalizasse o "além Édipo" em referência à lógica; com isso, acabou por articular a noção de primazia fálica de forma distinta de Freud e seus discípulos. Ou seja, o falo continuou a ser o único significante sexual, mas há duas possibilidades de inscrição na função fálica: todo ou não-todo. Em consequência, se há somente um significante da sexuação e este produz 
o homem, podemos dizer que ao nível inconsciente o Outro sexuado não existe. Eis o aforismo lacaniano: "A mulher não existe" — fruto da impossibilidade de encontrar do lado feminino um suporte identificatório que fundamente o ser dA mulher (BONFIM \& VIDAL, 2009).

\section{CONSIDERAÇÕES FINAIS}

No livro $A$ angústia, Lacan enfatiza o falo como uma função escópica da potência, como $(-\varphi)$ do órgão, referindo-se não apenas à castração edipiana, mas à castração entendida como o desaparecimento do órgão fálico no momento do orgasmo, de modo a destacar a angústia ao nível da detumescência. Não obstante, isso denota a construção lacaniana de articular o falo a um objeto que não se reduz à simbolização, o objeto a. Temos, então, uma perspectiva bastante distinta sobre o falo, mas que de modo algum pode ser tomada como uma recusa à noção de falo como significante. Tal perspectiva é bem evidente quando acompanhamos as construções seguintes sobre o falo no ensino lacaniano.

No Seminário 18, o significante é um semblante, e o falo, enquanto tal, também é elevado à categoria de semblante. Por conseguinte, no Seminário 20, Lacan se refere a dois tipos de gozo: um determinado pelo significante fálico e outro que escapa a ele, inserindo-se na discussão sobre a lógica do todo e não-todo fálico. Logo, é preciso considerar que, se há formas diferentes de se referir ao falo, isso tem relação com o percurso da clínica e os avanços teóricos possibilitados por ela.

Miller (2005) considera que Lacan, no Seminário 10, nos leva a abordar o objeto a como um termo que não é significante e que, portanto, emerge no regime da exceção. Parece que o falo está aqui situado nesse mesmo regime. Até então, tudo era passível de se articular em termos simbólicos — inclusive o real podia ser abordado assim. O livro $A$ angústia, contudo, demonstra que na estrutura da linguagem há algo que não pode ser reduzido ao significante, sendo "assimilado grosseiramente ao corpo vivo” (2005, p.24). Em outras palavras, o que se apresenta no Seminário 10 é o objeto a como real, além de situar-se a separação entre esse objeto e a linguagem.

No Seminário 20, encontramos uma forma distinta de abordar o falo. Este não está mais vinculado à exceção, mas ao regime do não-todo. O não-todo não abole nem contrapõe o significante, mas estende-se ao conjunto do significante. Trata-se do não-todo fálico, que vem apontar para o gozo suplementar na mulher. O que podemos extrair do livro Mais, ainda é que existe uma articulação entre o significante e o gozo. O corpo que goza diz de um corpo afetado pelo significante. Esse desenrolar da teoria, entretanto, já começa a ser evidenciado desde o Seminário 18, em que Lacan retira o objeto a do real e o articula ao semblante.

A construção da teoria lacaniana, sob esta forma tão desafiadora de ser apreendida, diz do próprio movimento da clínica, de uma lógica de entrada na psi- 
canálise, como sugere Costa (1998). Tal como Freud, que parte de uma confiança na interpretação e se depara com o esgotamento do significante, culminando nas elaborações sobre a pulsão de morte e o que chamamos de gozo, Lacan segue movimento semelhante. Assim, podemos inferir que as discussões lacanianas sobre o falo - como significante, seguido de sua articulação com o objeto a situado inicialmente como real, depois como semblante, chegando à lógica do todo e não-todo — não são pensamentos contraditórios ou descontínuos, mas apresentam intrínseca relação com o desenvolvimento das construções a respeito do real, que não revoga as contribuições anteriores — antes, redimensiona o aparato teórico-clínico de Lacan.

Como se sabe, ao longo do ensino de Lacan, assistimos a um deslocamento da ênfase que é posta nos três registros — do imaginário para o simbólico, chegando ao cercamento mais rigoroso da categoria real, até se atingir uma equivalência entre eles. Os registros real-simbólico-imaginário não podem ser isolados, sendo a topologia do nó borromeano o que melhor expressa a união entre os três. Coutinho Jorge (2000) indica-nos que o interesse crescente de Lacan pelo real é correlato à introdução do objeto a em sua obra, sendo este o que dá ao real seu verdadeiro estatuto. Com o que nos deparamos, ao longo do Seminário 10, senão a discussão a respeito do objeto a? Assim, neste livro há uma virada — todavia, inacabada - sobre o real em jogo na clínica psicanalítica, que não convém assimilarmos como uma elaboração definitiva e muito menos tomá-lo sem levarmos em consideração a depuração final presente nas teorizações lacanianas — no caso desta discussão, o falo como um significante, porém submetido à lógica do não-todo. Por outro lado, como observa Bernardes a respeito do livro A angústia, é importante "Procurar não tanto eliminar as inúmeras contradições, dificuldades e ambiguidades que esse texto, por ser um Work in Progress, nos oferece, mas sim resgatar a sua novidade hoje." (2007, p.2, grifo da autora).

Recebido em 15/3/2012. Aprovado em 25/6/2012.

\section{REFERÊNCIĀS}

ANDRÉ, S. (1998) O que quer uma mulher? Rio de Janeiro: Jorge Zahar Editor. BERNARDES, A. (2007) Pedaços que faltam (sobre a origem do objeto a). Latusa digital - Revista da Escola Brasileira de Psicanálise (EBP-Rio), n.31, nov/2007, ano 4. Disponível em: <http://www.latusa.com.br/digital_edit31.htm > Acesso em: 15/7/2009.

BONFIM, F.; VIDAL, P. (2009) A feminilidade na psicanálise: A controvérsia quanto à primazia fálica. Fractal: Revista de Psicologia, Niterói, 21(3), 539-548. 
BRANDÃO, J. (1991) Dicionário mítico-epistemológico, v.II (J-Z). Petrópolis $(\mathrm{RJ})$ : Vozes.

BRODSKY, G. (2008a) Um homem, uma mulher e a psicanálise. Latusa: O semblante e a comédia dos sexos — Revista da Escola Brasileira de Psicanálise (EBP-Rio), n.13. Rio de Janeiro: Contra Capa, 153-170.

CALDAS, H. (2008) "Saber fazer com a não-relação", in ALBERTI, S. (Org.) A sexualidade na aurora do século XXI. Rio de Janeiro: Cia. de Freud, p.375-385.

CAVICCHIOLI, M. (2008) "O falo na antiguidade e modernidade: uma leitura Foucaultiana”, in FUNARI, P. \& RAGO, M. (Orgs.) Subjetividades antigas e modernas. São Paulo: Annablume, p.237-250.

COSTA, A. (1998) A fiç̧ão de si mesmo: interpretação e ato em psicanálise. Rio de Janeiro: Cia. de Freud.

DEUTSCH, H. (1979) “La psicología de la mujer en relación con las funciones de reproducción”, in La femineidad como máscara. Barcelona: Tusquets, p.43-58.

FREUD. S. (1996) Obras psicológicas completas de Sigmund Freud. Edição standard brasileira. Rio de Janeiro: Imago.

(1905) “Três ensaios sobre a teoria da sexualidade”, v.VII, p.128-229.

(1923) “Organização genital infantil”, v.XIX, p.157-161.

(1924) “A dissolução do complexo de Édipo”, v.XIX, p.193-199.

(1925) "Algumas consequências psíquicas da diferença anatômica entre os sexos", v.XIX, p.277-286.

(1931) “Sexualidade feminina”, v.XXI, p.233-251.

(1932) "Conferência XXXIII — Feminilidade”, v.XXII, p.113-134.

(1938) "Esboço de sicanálise”, v.XIX, p.15-80 p.

JONES, E. (1977) "O desenvolvimento inicial da sexualidade feminina”, in . Papers on psychoanalysis. London: Maresfield Reprints, p.438-452.

JORGE, M. A. C. (2000) Fundamentos da psicanálise de Freud a Lacan. Rio de Janeiro: Jorge Zahar Editor.

HORNEY, K. (1924/1991) Psicologia feminina. Rio de Janeiro: Bertrand Brasil. (1939/1966) Os novos rumos da psicanálise. Rio de Janeiro: Civilização Brasileira.

KLEIN, M. (1986/1952) “Algumas conclusões teóricas sobre a vida emocional do bebê", in et al. Os progressos da psicanálise. 3 ed. Rio de Janeiro: Guanabara, p.216-255.

LACAN, J. (1956-57/1995) O Seminário 4-A relação de objeto. Rio de Janeiro: Jorge Zahar Editor.

.(1957-58/1999) O Seminário 5 - As formações do inconsciente. Rio de Janeiro: Jorge Zahar Editor.

.(1958/1998) “A significação do falo”, in Escritos. Rio de Janeiro: Jorge Zahar Editor, p.92-703.

.(1962-63/2005) O Seminário 10 — A angústia. Rio de Janeiro: Jorge Zahar Editor.

.(1971/2009) O Seminário 18 - De um discurso que não fosse semblante.

Rio de Janeiro: Jorge Zahar Editor. 
.(1972-73/1985) O Seminário 20 - Mais, ainda. Rio de Janeiro: Jorge Zahar Editor.

LEGUIL, F. (2008) “Falo”. Scilicet - Os objetos a na experiência psicanalítica. AMP. Rio de Janeiro: Contra Capa, p.121-123.

MILLER, J-A. (2005) Introdução à leitura e referências do Seminário 10. Opção Lacaniana — Revista Brasileira Internacional de Psicanálise, n.43, São Paulo: Eliota.

MOREL, G. (1997) Sexuação, gozo e identificação. Latusa - Revista da Escola Brasileira de Psicanálise (EBP-Rio), n.1. Rio de Janeiro: Contra Capa, p.89-112.

POLLO, V. (2003) “O debate dos anos 1930 e o retorno de Lacan”, in . Mulheres histéricas. Rio de Janeiro: Contra Capa, p.71-92.

RABINOVICH, D. (2005) A significação do falo: uma leitura. Rio de Janeiro: Cia. de Freud.

(2009) O conceito de objeto na teoria psicanalítica — suas incidências na direção da cura. Rio de Janeiro: Cia. de Freud.

RECALDE, M. (2008) "El Edipo femenino: un interrogante freudiano”, in MILLER, J.-A. et al. Del Edipo a la sexuación. Buenos Aires: Paidós, p.103-115.

SOLER, C. (2005) O que Lacan dizia das mulheres. Rio de Janeiro: Jorge Zahar Editor.

VIEIRA, M. A. (2008) Restos: uma introdução lacaniana ao objeto da psicanálise. Rio de Janeiro: Contra Capa.

ZACK, O. (2008) “O Édipo: um impasse”, in MILLER, J.-A. et al. Del Edipo a la sexuación. Buenos Aires: Paidós, p.159-167.

\author{
Ana Costa \\ medeirosdacostaanamaria@gmail.com \\ Flavia Bonfim \\ flaviabonfimpsi@yahoo.com.br
}


